THE CONSOLATIONS OF MORTALITY 
This page intentionally left blank 


\section{ANDREW STARK}

\section{The Consolations of Mortality}

Making Sense of Death

Yale UNIVERSITY PRESS NEW HAVEN AND LONDON 
Published with assistance from the foundation established in memory of James Wesley Cooper of the Class of i $86_{5}$, Yale College.

Copyright (C) 2016 by Yale University.

All rights reserved.

This book may not be reproduced, in whole or in part, including illustrations, in any form (beyond that copying permitted by Sections I07 and Io8 of the U.S. Copyright Law and except by reviewers for the public press), without written permission from the publishers.

Yale University Press books may be purchased in quantity for educational, business, or promotional use. For information, please e-mail sales.press@yale.edu (U.S. office) or sales@yaleup.co.uk (U.K. office).

Set in Janson Oldstyle and Futura Bold types by Newgen North America. Printed in the United States of America.

Library of Congress Control Number: 201693466 I ISBN 978-0-300-2 I 92 5-8 (cloth : alk. paper)

Quotation from "Stopping by Woods on a Snowy Evening" from the book The Poetry of Robert Frost, edited by Edward Connery Lathem. Copyright (C) I923, I969 by Henry Holt and Company, LLC. Copyright (C) I95 I by Robert Frost. Used by permission of Henry Holt and Company, LLC. All rights reserved.

Excerpt from "Aubade" from Collected Poems, by Philip Larkin. Copyright (C) I 988, 2003 by the Estate of Philip Larkin. Reprinted by permission of Farrar, Straus and Giroux, LLC.

"(Sittin' on) The Dock of the Bay," words and music by Otis Redding and Steve Cropper. Copyright (C) I 968 (Renewed) I 975 Irving Music Inc. All rights for the world outside of the U.S. controlled and administered by WB Music Corp. and Irving Music, Inc. All rights reserved. Used by permission of Alfred Music and Hal Leonard Corporation.

"Intimacy," words and music by Edgar Bronfman Jr. and Bruce Roberts. (C) I 995 Boozetunes and Bir. Copyright (C) I 992 Reservoir Media Music and WB Music Corp. All rights on behalf of Boozetunes administered by WB Music Corp. All rights reserved. Used by permission of Alfred Music and Hal Leonard Corporation.

"Cat's in the Cradle," Words and Music by Harry Chapin and Sandy Chapin. (C) I974 (Renewed) Story Songs, Ltd. All Rights Administered by WB Music Corp. All Rights Reserved. Used By Permission of Alfred Music.

A catalogue record for this book is available from the British Library.

This paper meets the requirements of ANSI/NISO Z39.48-I 992

(Permanence of Paper). 
For Deborah 
This page intentionally left blank 